\title{
СРАВНИТЕЛЬНАЯ ХАРАКТЕРИСТИКА ЩЕЛОЧНЫХ ПРИРАЗЛОМНЫХ МЕТАСОМАТИТОВ И ГРАНИТОИДОВ ЗОН РЕГИОНАЛЬНЫХ РАЗЛОМОВ В ИНТЕРВАЛЕ 2.1-1.6 МЛРД ЛЕТ В ЮЖНОМ ОБРАМЛЕНИИ СИБИРСКОЙ ПЛАТФОРМЫ
}

\begin{abstract}
Л.В. Кущ, В.А. Макрыгина
Институт геохимии им. А.П. Виноградова СО РАН, 664033, Иркутск, ул. Фаворского, 1а, Россия

Сопоставление геологического положения, этапов развития, возраста, геохимических особенностей метасоматитов и кислых магматитов вдоль южного края Сибирского кратона показало, что все изученные метасоматиты приурочены к разломам, оперяющим главную шовную зону кратона. От Бирюсинской зоны на юго-западе и далее на северо-восток, от Приморской зоны до Даванской зоны смятия и Катугино-Аянской зоны на Алдане при близком составе метасоматитов увеличивается их рудоносность. Процесс начинается с бластокатаклаза пород (безрудная стадия). На 2-м этапе вдоль зон бластокатаклазитов циркулируют калиевые рудоносные ( $\mathrm{Nb}, \mathrm{Zr}, \mathrm{Hf}$, РЗЭ) растворы, образуя собственно калиевые метасоматиты ранней щелочной стадии, которая проявляется как субщелочная гранитизация. Далее формируются грейзены (кислотная стадия) c Sn, Be, Th, U, W рудной нагрузкой. Магматический этап может проявляться до и после метасоматоза. На фоне продолжающихся тектонических движений он приводит к образованию рапакивиподобных гранитов, богатых теми же элементами. В это же время вдоль края кратона формируется крупнейший вулканоплутонический пояс, кислые вулканиты которого имеют близкие к метасоматитам и гранитам геохимические особенности. Возраст всех этих образований укладывается в интервал $2.1-1.6$ млрд лет.
\end{abstract}

Щелочные метасоматиты, гранитоиды, краевой шов платформы, оперяющие разломы, бластокатаклаз, редкометалльное оруденение.

\section{COMPARISON OF 2.1-1.6 GA FAULT-LINE ALKALINE METASOMATIC ROCKS AND GRANITOIDS FROM REGIONAL FAULT ZONES ON THE SOUTHERN FRAMING OF THE SIBERIAN CRATON}

\section{L.V. Kushch and V.A. Makrygina}

The geologic position, development stages, age, and geochemical features of metasomatic and felsic igneous rocks along the southern edge of the Siberian craton are compared. The comparison shows that all the studied metasomatic rocks are confined to the faults feathering the main suture zone of the craton. From Biryusa zone in the southwest and farther northeast, from Primor'e zone to Davan shear zone and Katugino-Ayan zone in the Aldan area, the metasomatic rocks are of similar composition but show higher mineralization. The process begins with blastocataclasis (barren stage). During the second stage, ore-bearing ( $\mathrm{Nb}, \mathrm{Zr}$, Hf, and REE) potassic solutions circulate along the blastocataclastic zones. They form metasomatic potassic rocks of the early alkaline stage, expressed subalkalic granitization. The next (acid) stage is marked by the formation of greisens with $\mathrm{Sn}$, $\mathrm{Be}, \mathrm{Th}, \mathrm{U}$, and $\mathrm{W}$ mineralization. The igneous stage might precede or follow the metasomatism. At the time of ongoing tectonic movements, it produces rapakivi-like granites rich in the same elements. Also, a huge volcanoplutonic belt develops along the craton edge during this time. The geochemical features of its felsic volcanics are close to those of the metasomatic rocks and granites. The age of all these rocks is within 2.1-1.6 Ga.

Alkaline metasomatic rocks, granitoids, marginal suture of the platform, feathering faults, blastocataclasis, rare-metal mineralization

\section{ВВЕДЕНИЕ}

Приразломные метасоматиты известны на многих докембрийских кратонах мира (Канадский, Индийский и Украинский щиты и др.). Они характеризуются рядом черт, присущих только этим образованиям: приуроченностью к зонам глубинных разломов в краевых частях платформ, протерозойским возрастом проявлений щелочного метасоматоза и сопряженностью с ними крупных месторождений редких металлов. Приразломные метасоматиты как самостоятельная формация метасоматических пород, характерная для протоплатформенных областей докембрия, выделена в семидесятых годах прошлого столетия. К ней относятся существенно полевошпатовые щелочные метасоматиты гранитовидного облика, с которыми связано $\mathrm{Be}, \mathrm{Sn}, \mathrm{Ta}, \mathrm{Nb}, \mathrm{Zr}, \mathrm{U}$ и Р3Э-оруденение. От похожих на них по составу и специализа- 


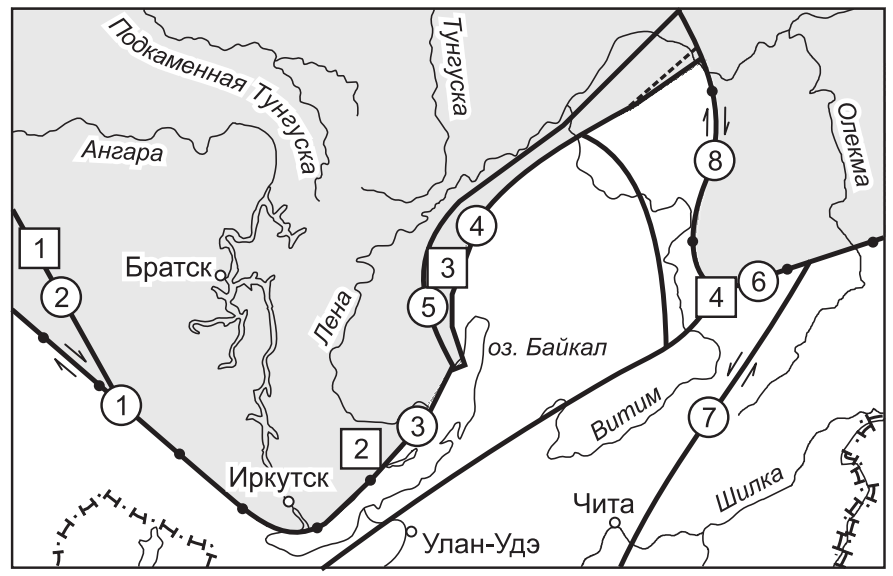

Рис. 1. Схема главных разломов краевого шва (линия с кружками) юга Сибирского кратона (серый тон).

Цифры в кружках: 1 - Главный Саянский разлом; 2 - Бирюсинский разлом; 3 - Приморский разлом; 4, 5 - Левоминьский и Даванский разломы; 6 - Каларский разлом; 7 - Каларско-Каренгский разлом, 8 - Жуинский разлом. Участки развития щелочных метасоматитов (цифры в квадратах): 1 - Бирюсинская зона, 2 - рапакивиподобные граниты с постмагматическими метасоматитами Приморского разлома; 3 - Даванская зона смятия; 4 - Катугино-Аянская зона.

ции редкоземельных пегматитов они отличаются структурами, приуроченностью к крупным глубинным разломам и отсутствием прямой связи с интрузивными образованиями. Основные характеристики приразломных метасоматитов описаны в работах А.И. Гинзбурга и др. [Гинзбург, Апельцин, 1970; Гинзбург и др., 1973], В.А. Рудника и др. [1970], Ф.Р. Апельцина [1972], В.И. Казанского и др. [1978], В.Г. Кушева [1972], Я.Н. Белевцева [1979], К.В. Прохорова, В.Н. Собаченко [1985], В.Н. Собаченко [1975, 1985, 1998], В.В. Булдыгерова, В.Н. Собаченко [2005] и других. В нашей стране аналитические материалы по редкометалльным месторождениям были недоступны, поэтому проводить сравнения вещественного состава этих образований достаточно трудно. Мы остановились на метасоматитах Сибирского кратона, по которым у нас есть собственные аналитические материалы и наблюдения. Эта статья является продолжением работ В.Н. Собаченко. Описанные в ней районы принадлежат к зонам разломов южного краевого шва Сибирской платформы, характеризуются развитием щелочных метасоматитов и наличием рудопроявлений редких металлов. Но степень рудоносности их сильно различается - от слабобериллиеносных метасоматитов Бирюсинской зоны в юго-западной части шва к рудопроявлениям редких металлов в зоне Приморского разлома и далее на северо-восток - к промышленно значимым рудопроявлениям в Даванской зоне смятия и до крупнейшего Катугинского редкометалльного месторождения в краевой части Алданского щита Сибирской платформы (рис. 1), также связанного на ранних этапах с развитием щелочных метасоматитов. Особенностью приразломных метасоматитов в краевых частях Сибирского кратона является более мощное развитие ранней щелочной стадии процесса по сравнению с украинскими и канадскими метасоматитами, где наиболее продуктивной и широко развитой является поздняя щелочная - альбитовая стадия. Еще одной их особенностью является близость геохимических характеристик с рапакивиподобными гранитами и кислыми вулканитами Северо-Байкальского вулканоплутонического пояса. В этой статье сделана попытка сравнить геохимические особенности всех этих образований, выяснить причины их близости и сопоставить с их тектонической позицией.

\section{ОСОБЕННОСТИ ГЕОЛОГИИ И ТЕКТОНИЧЕСКИХ СТРУКТУР, К КОТОРЫМ ПРИУРОЧЕНЫ МЕТАСОМАТИТЫ}

Сравниваемые участки развития метасоматитов имеют сложную геологическую историю, имевшую несколько временных этапов. Это отражается в таблице возрастных определений, которых явно недостаточно для такой большой территории. Но все они укладываются в интервал от 2.1 до 1.6 млрд лет (табл. 1). Палеопротерозойские возрасты отражают метаморфизм и ранний этап гранитообразования. Мезопротерозой охватывает несколько этапов формирования гранитов и метасоматитов.

Рассмотрим особенности строения и последовательность геологических событий на каждом участке в направлении с юго-запада на северо-восток.

Бирюсинский разлом длиной более 250 км под острым углом ответвляется от Главного Саянского разлома, но именно вдоль него наиболее сильно проявляется наложенный дислокационный метаморфизм протерозойского возраста (первый этап) и сопряженные с ним процессы тектонической и метасоматической переработки прилегающих к разлому метаморфических пород. Этот факт приводит даже к дискуссиям среди геологов о том, которую из структур считать краевым швом платформы [Мехоношин и др., 2005]. В зону переработки вдоль Бирюсинского разлома попадают в основном биотитовые, гранатбиотитовые, биотит-амфиболовые гнейсы, амфиболиты, двупироксеновые кристаллосланцы и мигматиты хайламинской серии. По составу они восстанавливаются как метавулканиты, метаграувакки и метаалевролиты. Типичные метаосадки (доломитовые мраморы, кварциты, гранат-биотит-дистеновые и гранат-биотит-силлиманитовые сланцы) появляются только в алхадырской свите неройской серии и ле- 
Таблица 1. Данные о возрасте вмещающих пород, бластокатаклазитов, щелочных метасоматитов, гранитоидов и метасоматитов поздней щелочной стадии

\begin{tabular}{|c|c|c|c|c|}
\hline $\begin{array}{c}\text { Структурная зона, ин- } \\
\text { трузивный комплекс }\end{array}$ & Порода & Метод & $\begin{array}{l}\text { Возраст, } \\
\text { млн лет }\end{array}$ & Ссылка \\
\hline $\begin{array}{l}\text { Зона Бирюсинского } \\
\text { разлома }\end{array}$ & $\begin{array}{l}\text { Гнейсы хайламинской свиты } \\
\text { Гранитоиды саянского комплекса } \\
\text { Гранодиориты саянского комплекса } \\
\text { Субщелочные метасоматиты }\end{array}$ & $\begin{array}{l}\mathrm{Rb}-\mathrm{Sr}, \text { вал } \\
\mathrm{Rb}-\mathrm{Sr}, \text { вал } \\
\mathrm{U}-\mathrm{Pb}, \text { циркон } \\
\mathrm{Rb}-\mathrm{Sr} \text {, вал }\end{array}$ & $\begin{array}{c}2700-2800 \\
1858 \pm 20 \\
1848 \pm 0.018 \\
1652 \pm 100\end{array}$ & $\begin{array}{l}\text { [Туркина и др., 2003] } \\
\text { [Левицкий и др., 2002] } \\
\text { [Кирнозова и др., 2000] } \\
\text { [Собаченко и др., 1998] }\end{array}$ \\
\hline $\begin{array}{l}\text { Зона Приморского } \\
\text { разлома (Зап. При- } \\
\text { байкалье) }\end{array}$ & $\begin{array}{l}\text { Сарминская серия } \\
\text { Тектониты иликтинской свиты } \\
\text { Сланцы анайской свиты } \\
\text { Рапакивиподобные граниты при- } \\
\text { морского комплекса } \\
\text { » } \\
\text { » } \\
\text { Щелочные метасоматиты в примор- } \\
\text { ских гранитах }\end{array}$ & $\begin{array}{l}\mathrm{U}-\mathrm{Pb}, \text { циркон } \\
\mathrm{Nd}, T(\mathrm{DM}) \\
\mathrm{U}-\mathrm{Pb}, \text { циркон } \\
\text { » } \\
\text { " } \\
\mathrm{Pb}-\mathrm{Pb}, \text { циркон }\end{array}$ & $\begin{array}{c}1890 \pm 25 \\
2817 \\
1864 \pm 19 \\
1910 \pm 30 \\
1859 \pm 16 \\
1803.6 \pm 1.1\end{array}$ & $\begin{array}{l}\text { [Гореванов, Халилов, 1995] } \\
\text { [Макрыгина и др., 2005] } \\
\text { [Бухаров и др., 1992] } \\
\text { [Гольцман и др, 1982] } \\
\text { [Донская и др., 2003] } \\
\text { Бибиткова, Собаченко, уст- } \\
\text { ное сообщение }\end{array}$ \\
\hline $\begin{array}{l}\text { Даванская зона смя- } \\
\text { тия Чуйское поднятие }\end{array}$ & \begin{tabular}{l} 
Плагиограниты \\
\multicolumn{1}{|c}{ ” } \\
Абчадские граносиениты \\
Щелочные метасоматиты \\
Аляскитовые граниты \\
Гнейсограниты
\end{tabular} & $\begin{array}{c}\mathrm{U}-\mathrm{Pb}, \text { циркон } \\
\text { " } \\
\text { ” } \\
\text { ” } \\
\mathrm{Rb}-\mathrm{Sr} \text {, вал } \\
\mathrm{Rb}-\mathrm{Sr}, \text { вал }\end{array}$ & $\begin{array}{c}1910 \pm 30 \\
1866 \pm 6 \\
1860 \pm 30 \\
1740 \pm 50 \\
1715 \pm 4 \\
1560 \pm 72\end{array}$ & $\begin{array}{l}\text { [Срывцев, 1980] } \\
\text { [Неймарк и др., 1991] } \\
\text { [Неймарк и др., 1987] } \\
\text { [Неймарк, 1985] } \\
\text { [Собаченко и др., 1988] } \\
\text { » }\end{array}$ \\
\hline $\begin{array}{l}\text { Катугино-Аянская } \\
\text { зона (СВ Забайкалье) }\end{array}$ & $\begin{array}{l}\text { Метасоматиты } \\
\text { Щелочные граниты } \\
\text { Граниты катугинского комплекса } \\
\text { Приразломные метасоматиты } \\
\text { Рапакиви каларского массива } \\
\text { Граниты кодарского комплекса } \\
\text { Андезиты }\end{array}$ & $\begin{array}{l}\mathrm{U}-\mathrm{Pb} \text { пирохлор } \\
\mathrm{Rb}-\mathrm{Sr} \text {, вал } \\
\mathrm{U}-\mathrm{Pb}, \text { циркон } \\
\mathrm{Rb}-\mathrm{Sr} \text {, вал } \\
\quad \text { » } \\
\mathrm{U}-\mathrm{Pb}, \text { циркон } \\
\quad \text { » }\end{array}$ & $\begin{array}{c}2100 \pm 120 \\
2100 \pm 120 \\
2066 \pm 6 \\
2014 \pm 20 \\
1800 \pm 100 \\
1873 \pm 5 \\
1869 \pm 6\end{array}$ & $\begin{array}{l}\text { [Миркина, 1983] } \\
\text { [Таусон и др., 1983] } \\
\text { [Ларин и др., 2002] } \\
\text { [Таусон и др., 1983] } \\
\text { » } \\
\text { [Ларин и др., 2000] } \\
\text { [Ларин и др., 2003] }\end{array}$ \\
\hline
\end{tabular}

жат несогласно, в виде удлиненных прогибов на породах хайламинской серии [Сезько, 1988]. Породы хайламинской серии претерпели метаморфизм гранулитовой фации, а затем мигматизацию и регрессивный метаморфизм в условиях амфиболитовой фации повышенных давлений [Колотилина и др., 2001]. Повышенных относительно верхней коры концентраций редких элементов в продуктах метаморфизма и мигматизации на этом этапе не обнаружено (табл. 2).

На всем протяжении зоны Бирюсинского разлома широко развит приразломный дислокационный метаморфический комплекс. Характернейшими породами зоны являются мелко- и тонкозернистые, часто очковые, с порфирокластами и порфиробластами полевых шпатов бластокатаклазиты и бластомилониты [Кущ, 2010]. Мощность зон бластомилонитов этого типа в отдельных пересечениях достигает $1500-2000 \mathrm{M}$.

На рубеже палео- и мезопротерозоя, по-видимому, произошла активизиция тектонических движений со снижением давления и увеличением проницаемости пород для более высокотемпературных растворов. Начинается второй этап - формирование основной массы приразломных метасоматитов, проявляющихся в виде калишпатизации с образованием биотитовых и гастингсит-биотитовых гранитовидных пород с реликтами бластокатаклазитов. Количество калишпата может достигать 60 об. \%. Зоны их развития уверенно трассируются результатами аэрогаммаспектрометрической съемки по аномалиям содержаний K и Th (В.В. Ромашко, устное сообщение). Этап высокой активности калия отвечает ранней щелочной стадии приразломного метасоматоза. Полевошпатовый метасоматоз наиболее интенсивно проявлен по бластомилонитам амфиболитовой фации. В метасоматитах почти не проявляются низкотемпературные преобразования в виде окварцевания, мусковитизации и хлоритизации, т.е. кислотной волны приразломного метасоматоза. 


\begin{tabular}{|c|c|c|c|c|c|c|c|c|c|}
\hline \multirow{2}{*}{ Компонент } & \multicolumn{5}{|c|}{ Зона Бирюсинского разлома } & \multicolumn{4}{|c|}{ Приморский разлом } \\
\hline & 1 & 2 & 3 & 4 & 5 & 6 & 7 & 8 & 9 \\
\hline $\mathrm{SiO}_{2}$, мac. $\%$ & 60.96 & 62.47 & 71.95 & 73.16 & 71.79 & 74.00 & 75.44 & 72.70 & 73.00 \\
\hline $\mathrm{TiO}_{2}$ & 0.17 & 0.93 & 0.40 & 0.32 & 0.28 & 0.26 & 0.20 & 0.03 & 0.04 \\
\hline $\mathrm{Al}_{2} \mathrm{O}_{3}$ & 13.11 & 15.98 & 13.73 & 13.16 & 14.03 & 12.62 & 11.90 & 13.55 & 18.35 \\
\hline $\mathrm{Fe}_{2} \mathrm{O}_{3}$ & 3.73 & 2.74 & 1.40 & 0.83 & 1.39 & 2.13 & 1.33 & 0.31 & 0.53 \\
\hline $\mathrm{FeO}$ & 2.87 & 4.32 & 1.33 & 1.79 & 0.98 & 1.39 & 1.18 & 0.25 & 0.21 \\
\hline $\mathrm{MnO}$ & 0.01 & 0.13 & 0.04 & 0.04 & 0.02 & 0.04 & 0.03 & 0.05 & 0.03 \\
\hline $\mathrm{MgO}$ & 2.35 & 2.22 & 0.45 & 0.34 & 0.10 & 0.29 & 0.20 & 0.21 & 0.30 \\
\hline $\mathrm{CaO}$ & 4.82 & 3.88 & 0.17 & 0.21 & 0.72 & 0.95 & 0.62 & 0.15 & 0.24 \\
\hline $\mathrm{Na}_{2} \mathrm{O}$ & 2.86 & 3.05 & 3.20 & 3.46 & 2.10 & 2.65 & 2.65 & 3.38 & 0.25 \\
\hline $\mathrm{K}_{2} \mathrm{O}$ & 3.08 & 3.74 & 4.79 & 5.62 & 7.36 & 5.25 & 5.66 & 5.15 & 4.47 \\
\hline $\mathrm{P}_{2} \mathrm{O}_{5}$ & 0.28 & 0.28 & 0.12 & 0.57 & 0.02 & 0.07 & 0.05 & 0.01 & 0.30 \\
\hline $\mathrm{H}_{2} \mathrm{O}^{+}$ & 1.98 & 1.24 & 0.62 & 0.10 & 0.88 & 0.10 & 0.03 & 0.89 & 0.76 \\
\hline $\mathrm{F}$ & 0.10 & 0.13 & 0.04 & 0.20 & 0.19 & 0.22 & 0.29 & 0.02 & 1.20 \\
\hline Сумма & 100.00 & 99.79 & 99.73 & 100.00 & 99.86 & 99.97 & 99.57 & 99.63 & 99.68 \\
\hline $\mathrm{Li}, \Gamma / \mathrm{T}$ & 75 & 74 & 55 & 18 & 13 & 12 & 23 & 20 & 121 \\
\hline $\mathrm{Rb}$ & 115 & 167 & 182 & 296 & 97 & 205 & 344 & 764 & 560 \\
\hline $\mathrm{Ba}$ & 1024 & 1856 & 1501 & 439 & 1650 & 1898 & 365 & 600 & 560 \\
\hline $\mathrm{Sr}$ & 393 & 364 & 230 & 83 & 712 & 161 & 62 & 75 & 25 \\
\hline $\mathrm{Be}$ & 2.1 & 8.15 & 3.9 & 32 & 9 & 2.18 & 3.2 & 3.6 & 4.8 \\
\hline $\mathrm{Sn}$ & 6.5 & 7.5 & 7.8 & 13.8 & 12.5 & 4.87 & 8.8 & 34 & 54 \\
\hline $\mathrm{La}$ & 52 & 79 & 51 & 104 & 89 & 104 & 178 & 109 & 112 \\
\hline $\mathrm{Ce}$ & 108 & 142 & 112 & 153 & 150 & 182 & 318 & 182 & 200 \\
\hline $\mathrm{Nd}$ & 47 & 65.4 & 38 & 72 & 68 & 75.3 & 115 & 50 & 92 \\
\hline $\mathrm{Yb}$ & 3 & 4.6 & 2.4 & 8 & 5.2 & 4 & 5.3 & 7 & 10 \\
\hline $\mathrm{Y}$ & 27 & 37.6 & 23 & 58 & 41 & 44 & 53 & 37 & 64 \\
\hline $\mathrm{Zr}$ & 174 & 355 & 337 & 450 & 159 & 288 & 238 & 232 & 374 \\
\hline $\mathrm{Hf}$ & 4 & 8 & 15 & 5.9 & 4.4 & 9.3 & 12.2 & 12 & 9.3 \\
\hline $\mathrm{Nb}$ & 8.42 & 19.83 & 21.6 & 9.6 & 6.65 & 8.3 & 29.3 & 17 & 22 \\
\hline $\mathrm{Ta}$ & 0.43 & 1.03 & 1.17 & 1 & 0.55 & 0.9 & 1.2 & 5.6 & 7.2 \\
\hline Th & 12 & 40 & 14.3 & 93.8 & 37 & 36 & 55.7 & 52.8 & 81.5 \\
\hline $\mathrm{U}$ & 4.7 & 6.6 & 9.2 & 9.7 & 8.2 & 5.97 & 11.7 & 11.7 & 22.45 \\
\hline B & Не опр. & Не опр. & Не опр & Не опр. & Не опр. & 12.3 & 14.3 & Не опр. & Не опр. \\
\hline$n$ & 23 & 38 & 19 & 52 & 9 & 6 & 6 & 13 & 5 \\
\hline
\end{tabular}

Примечание. Бирюсинский разлом: 1 - гнейсы хайламинской толщи; 2 - бластотектониты; 3 - гранитоиды саянского комплекса; 4 - щелочные калиевые метасоматиты; 5 - мусковит-кварц-альбитовые метасоматиты. Приморский комплекс: 6 - рапакивиподобные граниты 1-я фаза, 7 - мелкозернистые биотитовые граниты 2-я фаза; 8 - микроклин-альбитовые постмагматические метасоматиты (р. Улан-Хан); 9 - топаз-мусковит-кварцевые грейзены [Базарова, 2011]. Не опр. - элемент не определялся, $n$ - число проб.

Непосредственной связи гранитовидных субщелочных метасоматитов с определенными гранитоидными массивами не наблюдается. В пространстве и во времени граниты разобщены с метасоматитами - возраст гранитов саянского комплекса составляет $1858 \pm 20$ млн лет, a $\mathrm{Rb}-\mathrm{Sr}$ возраст метасоматитов равен $1652 \pm 100$ млн лет при первичном отношении $\left({ }^{86} \mathrm{Sr} /{ }^{87} \mathrm{Sr}\right)_{0}=0.7175 \pm 0.0341$ [Собаченко и др., 1998] (см. табл. 1).

Зона Приморского глубинного разлома протягивается более чем на 200 км вдоль западного берега оз. Байкал. Вдоль нее выходят граниты приморского комплекса, которые имеют тектонические и очень редко интрузивные контакты с породами сарминской серии палеопротерозоя. Породы комплекса образуют Приморский хребет и южную часть Байкальского хребта. Для первой фазы гранитов характерны структуры протоклаза, с ориентированным «потоком» вкрапленников, которая свидетельствует о 
кристаллизации гранитоидов в процессе продвижения расплава вверх. С этим же связано появление овоидных структур, сближающих эти образования с гранитами-рапакиви. Продвижение частично раскристаллизованного расплава вверх приводит к его перегреву и кристаллизации плагиоклазовых оторочек вокруг ранее возникших вкрапленников калиевого полевого шпата. Зона Приморского разлома проходит также по породам сарминской серии, которая сложена разнообразными сланцами, кварцитосланцами, кварцитами, силикатно-карбонатными породами и доломитовыми мраморами. Милонитизированные хлоритовые сланцы, кварцитосланцы и кварциты анайской и иликтинской свит северного крыла разлома метаморфизованы в зеленосланцевой фации [Макрыгина и др., 2007]. На всем протяжении зоны Приморского разлома прослеживаются: 1) бластотектониты, развитые по метаморфическим породам и мигматитам; 2) протоклазовые структуры в ранней фазе овоидных рапакивиподобных гранитов; 3) катаклазированные аляскитовые граниты поздней фазы [Собаченко, 1975]. На этом участке щелочная стадия метасоматоза проявлена слабо, возможно, в связи с широким внедрением субщелочных калиевых гранитов, внутри которых они и развиты, и метасоматоз является постмагматическим процессом с более широким развитием кислотной стадии процесса.

Даванская зона смятия образовалась на участке сближения двух разломов - Левоминьского (Малоакитканского) и Даванского (Абчадского), отходящих на северо-северо-восток под острым углом от краевого шва платформы. В зону смятия попадают главным образом породы чуйской серии Чуйского поднятия, но, по данным ряда исследователей [Булдыгеров, Собаченко, 2005], и метавулканиты СевероБайкальского вулканоплутонического пояса (СБВПП). Поскольку породы Олокитского прогиба надвинуты на породы Чуйского поднятия [Макрыгина, 1991], краевой шов платформы должен проходить южнее (в районе Маректинского выступа и мыса Онокачанский), а указанные два разлома являются оперяющими по отношению к краевому шву. Для Даванской зоны смятия характерна еще более мощная тектоническая и метасоматическая переработка пород, чем для зоны Бирюсинского и Приморского разломов и очень сложные взаимоотношения пород.

Протолитом Даванской зоны смятия являются породы укучиктинской свиты чуйской серии. Они представлены биотитовыми, амфибол-биотитовыми и биотит-амфиболовыми гнейсами, с редкими прослоями гранат-биотит-амфиболовых гнейсов и пластовыми телами ортоамфиболитов. Вся толща по результатам геохимического изучения реставрируется как островодужные вулканиты активной континентальной окраины [Макрыгина, 1981]. Особенностью укучиктинской толщи является отсутствие кварцитов и карбонатных пород за исключением маломощной свиты тремолитовых мраморов, протянувшейся вдоль Абчадского разлома и являющейся, скорее всего, остатком сползшего надвига Олокитского синклинория, так как они подстилаются милонитами укучиктинской свиты [Макрыгина, 1991]. Метаморфизм пород отвечает амфиболитовой фации, на севере Чуйского поднятия он четко наложен на гранулитовый метаморфизм низких давлений, судя по реликтовым участкам двупироксеновых сланцев. Связанная с этими этапами гранитизация привела к образованию мигматитов, бедных редкими элементами по сравнению как с исходными гнейсами, так и с продуктами поздней субщелочной гранитизации (рис. 2).

Последующие сдвиговые движения вдоль разломов привели к увеличению проницаемости в отдельных зонах и к поступлению растворов с формированием второго этапа - мощных проявлений калиевого щелочного метасоматоза (ранняя щелочная стадия). Гранитовидные метасоматиты трудно диагностируются. При замещении метаморфических пород они структурно похожи на мигматиты [Макрыгина, 1981], при развитии по гранитоидам их можно выделить только по предваряющему катаклазу пород. Главный критерий их выявления - резкое обогащение редкими высокозарядными элементами (Zr, Nb, РЗЭ - табл. 3, см. рис. 2).

Катугинское проявление метасоматитов располагается в пределах Катугино-Аянской зоны, расположенной на периферии Катугинского трога. Троговые структуры в Кодаро-Удоканском районе были заложены на архейском кристаллическом фундаменте в раннепротерозойское время и ограничивают крупный протоплатформенный прогиб [Архангельская и др., 1993]. Катугинский трог выполнен метаосадочными породами удоканской серии палеопротерозоя. Они метаморфизованы в температурных условиях амфиболитовой фации и не

Рис. 2. Спайдер-диаграмма для гнейсов чуйской серии (1); гранитогнейсов ранней гранитизации (2); мигматитов и гранитогнейсов субще-

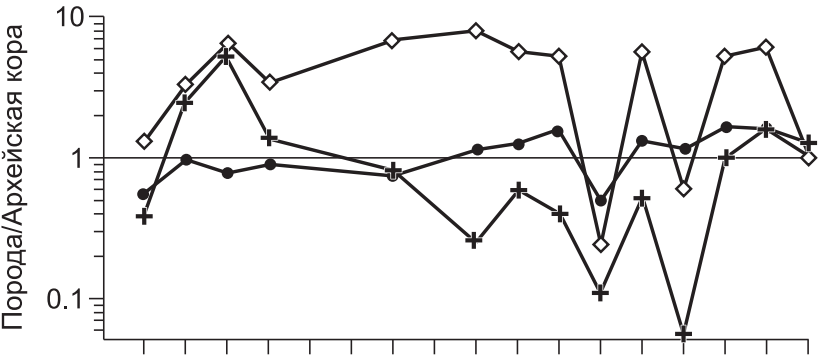

Li K RbBa Th U Nb Ta La CeNd Sr Zr Ti Y Yb B лочной гранитизации (3). 
Средние составы пород в Даванской и Катугино-Аянской зонах

\begin{tabular}{|c|c|c|c|c|c|c|c|c|c|c|c|c|}
\hline \multirow{2}{*}{ Компонент } & \multicolumn{6}{|c|}{ Даванская зона } & \multicolumn{6}{|c|}{ Катугино-Аянская зона } \\
\hline & 1 & 2 & 3 & 4 & 5 & 6 & 7 & 8 & 9 & 10 & 11 & 12 \\
\hline $\mathrm{SiO}_{2}$, мac. \% & 58.14 & 74.70 & 73.51 & 73.59 & 75.82 & 77.28 & 66.49 & 72.42 & 71.15 & 68.89 & 73.29 & 69.41 \\
\hline $\mathrm{TiO}_{2}$ & 1.42 & 0.07 & 0.19 & 0.28 & 0.30 & 0.05 & 0.95 & 0.22 & 0.61 & 0.36 & 0.25 & 0.16 \\
\hline $\mathrm{Al}_{2} \mathrm{O}_{3}$ & 16.45 & 13.50 & 13.77 & 12.61 & 11.68 & 13.05 & 17.80 & 13.60 & 13.12 & 13.44 & 12.00 & 11.82 \\
\hline $\mathrm{Fe}_{2} \mathrm{O}_{3}$ & 3.01 & 0.40 & 0.51 & 0.50 & 0.68 & 0.32 & 0.47 & 1.56 & 1.10 & 1.42 & 1.48 & 2.7 \\
\hline $\mathrm{FeO}$ & 6.82 & 0.72 & 1.49 & 2.96 & 1.80 & 0.74 & 5.75 & 0.99 & 2.99 & 2.00 & 1.18 & 2.87 \\
\hline $\mathrm{MnO}$ & 0.25 & 0.03 & 0.03 & 0.06 & 0.05 & 0.02 & 0.04 & 0.05 & 0.07 & 0.08 & 0.04 & 0.09 \\
\hline $\mathrm{MgO}$ & 1.45 & 0.17 & 0.36 & 0.16 & 0.09 & 0.45 & 1.03 & 0.46 & 0.86 & 2.46 & 0.10 & 0.01 \\
\hline $\mathrm{CaO}$ & 4.70 & 1.30 & 1.17 & 0.58 & 0.92 & 0.60 & 1.09 & 1.21 & 1.47 & 3.06 & 0.38 & 0.38 \\
\hline $\mathrm{Na}_{2} \mathrm{O}$ & 4.05 & 4.10 & 3.99 & 3.03 & 2.94 & 3.63 & 1.22 & 3.26 & 2.17 & 3.48 & 3.69 & 6.75 \\
\hline $\mathrm{K}_{2} \mathrm{O}$ & 2.00 & 4.26 & 4.72 & 5.29 & 5.17 & 3.29 & 3.34 & 4.96 & 4.82 & 3.84 & 4.43 & 3.88 \\
\hline $\mathrm{P}_{2} \mathrm{O}_{5}$ & 0.40 & 0.01 & 0.03 & 0.03 & 0.05 & 0.01 & 0.13 & 0.03 & 0.21 & 0.31 & 0.01 & 0.01 \\
\hline $\mathrm{H}_{2} \mathrm{O}^{+}$ & 0.48 & 0.07 & 0.59 & 0.20 & 0.54 & 0.31 & 1.44 & 0.80 & 0.80 & 0.64 & 0.85 & 0.13 \\
\hline F & 0.06 & 0.07 & 0.11 & 0.60 & 0.12 & 0.98 & 0.45 & 0.11 & 0.42 & 0.14 & 1.10 & 3.4 \\
\hline Сумма & 99.23 & 99.40 & 100.36 & 99.86 & 100.16 & 100.72 & 100.20 & 100.00 & 99.80 & 99.98 & 99.80 & 101.61 \\
\hline $\mathrm{Li}, \Gamma / \mathrm{T}$ & 10 & 13 & 16 & 19 & 12.5 & 29 & 37 & 33 & 59 & 14 & 104 & 464 \\
\hline $\mathrm{Rb}$ & 36 & 342 & 380 & 341 & 280 & 346 & 345 & 204 & 365 & 210 & 392 & 1088 \\
\hline $\mathrm{Ba}$ & 1100 & 930 & 932 & 1400 & 783 & 1530 & 675 & 1366 & 440 & 877 & 330 & 24 \\
\hline $\mathrm{Sr}$ & 180 & 25 & 83 & 150 & 52 & 63 & 171 & 130 & 68 & 214 & 31 & 25 \\
\hline $\mathrm{Be}$ & 4.8 & 7.2 & 5.7 & 9 & 7.8 & 34 & 3.9 & 2.04 & 6.7 & 5.8 & 3 & 20 \\
\hline Sn & 5 & 4 & 8 & 24 & 9.6 & 1230 & 5.6 & 6.9 & 14.7 & 25.8 & 57.2 & 6.6 \\
\hline $\mathrm{La}$ & 62 & 5 & 49 & 168 & 131 & 360 & 99 & 125 & 93 & 101 & 190 & 210 \\
\hline $\mathrm{Ce}$ & 135 & 25 & 146 & 320 & 210 & 850 & 160 & 210 & 150 & 160 & 390 & 860 \\
\hline $\mathrm{Nd}$ & 58 & 8 & 92 & 80 & 99 & 350 & 80 & 64 & 68 & 69 & 140 & 210 \\
\hline $\mathrm{Yb}$ & 7.2 & 2 & 18.3 & 37 & 13 & 59 & 11 & 2.4 & 3.2 & 4.5 & 7.8 & 26 \\
\hline Y & 64 & 15 & 78.9 & 101 & 92 & 113 & 80.3 & 17 & 28 & 36 & 47 & 120 \\
\hline $\mathrm{Zr}$ & 110 & 40 & 345 & 690 & 406 & 500 & 418 & 300 & 635 & 505 & 699 & 4000 \\
\hline $\mathrm{Hf}$ & 3.2 & 1.2 & 11 & 24.2 & 13.5 & 17.7 & 10.5 & 7.96 & 15.9 & 11.6 & 12.17 & 170 \\
\hline $\mathrm{Nb}$ & 2.5 & 8.6 & 12.3 & 76 & 55.6 & 54 & 14.3 & 24 & 19.7 & 41.8 & 103 & 4400 \\
\hline $\mathrm{Ta}$ & 0.2 & 0.5 & 9.6 & 2.3 & 1.19 & 11 & 9.3 & 2.7 & 1.46 & 3.19 & 48 & 250 \\
\hline Th & Не опр. & Не опр. & 29 & 55 & 26 & 62 & 22 & 31 & 16 & 30.6 & 146 & 211 \\
\hline $\mathrm{U}$ & » & " & 17.8 & 12 & 20.5 & 27 & 15.3 & Не опр. & Не опр. & 11 & Не опр. & Не опр. \\
\hline B & 3.5 & 1.5 & Не опр. & Не опр. & Не опр. & Не опр. & Не опр. & " & 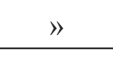 & Не опр. & " & $\gg$ \\
\hline$n$ & 6 & 8 & 8 & 19 & 11 & 9 & 7 & 6 & 7 & 14 & 13 & 15 \\
\hline
\end{tabular}

Примечание. Даванская зона смятия: 1 - гнейсы укучиктинской толщи; 2 - биотитовые гранитогнейсы ранней гранитизации, 3 - грубоочковые бластотектониты; 4 - щелочные калишпатовые метасоматиты; 5 - аляскитовые граниты ирельского комплекса; 6 - грейзены. Катугино-Аянская зона: 7 - биотитовые сланцы удоканской серии; 8 - мигматиты ранней гранитизации; 9 - крупноочковые бластотектониты; 10 - гранитовидные калишпатовые метасоматиты; 11 - рапакиви кодарского комплекса, 12 - натриевые метасоматиты.

несут повышенных концентраций редких элементов. Здесь же ограниченно развиты субщелочные метабазальты (амфиболиты). На метаморфическом этапе в породах широко проявлена гранитизация нормальной щелочности, не сопровождающаяся ростом концентраций редких элементов. Аэрогеофизическими работами [Генко и др., 1977] в пределах Катугинского поля установлен изгиб границы между гравитационными максимумами и минимумами, который пространственно совмещен с локальным понижением магнитного поля. Эти данные подтверждают глубинный тип геологической структуры, в которой располагаются крупные тела щелочных гранитоподобных метасоматитов с редкометалльным оруденением. 


\section{ГЕОХИМИЧЕСКИЕ ОСОБЕННОСТИ ЩЕЛОЧНЫХ МЕТАСОМАТИТОВ И ГРАНИТОИДОВ}

Геохимия щелочных метасоматитов трех обсуждаемых районов, а также гранитоидов и метасоматитов приморского комплекса изучалась в разное время В.Н. Собаченко, Л.В. Кущ, В.А. Макрыгиной, В.В. Архангельской, Е.П. Базаровой и другими, но никогда не проводилось сравнения этих объектов между собой и с другими гранитоидными образованиями. Только в работе [Петрова и др., 1997] было отмечено вещественное сходство гранитов рапакиви и кислых вулканитов и сделан вывод об их парагенетической связи. Ведь помимо сходного тектонического положения и последовательности образования пород, их геохимические особенности очень близки. Поскольку мы работали на всех этих участках и получили аналитический материал, выполненный в лабораториях ИГХ СО РАН, появилась возможность для корректного сравнения особенностей состава метасоматических и гранитоидных пород.

Аналитические методы. Силикатные анализы выполнены методом РФА, аналитик А.Л. Финкельштейн по стандартной методике [Afonin et al., 1992] с ошибкой $0.5-5 \%$, щелочные элементы выполнены методом фотометрии пламени с ошибкой 5-10\% Л.Н. Матвеевой, редкие элементы определялись количественным атомно-эмиссионным методом С.К. Ярошенко, Л.Л. Петровым, О.М. Чернышевой, С.С. Воробьевой и др. с ошибкой $10-20 \%$. РЗЭ проанализированы методом ICP-MS Г.П. Сандимировой и Е.В. Смирновой $(\sigma \pm 5-10 \%)$. Все анализы проводились в ИГХ СО РАН по стандартным методикам с использованием аттестованных стандартов [Geostandards..., 1994].

Зона Бирюсинского разлома. По геохимическим особенностям гранитовидные метасоматиты Бирюсы имеют слабоповышенные по сравнению со стандартными известково-щелочными гранитами $\mathrm{Nb}, \mathrm{Zr}, \mathrm{P} 3 Э, \mathrm{Th}, \mathrm{F}$, и по этим признакам они наиболее близки гранитоидам саянского комплекса [Собаченко, Кущ, 2005]. Но в пространстве и во времени граниты разобщены с метасоматитами (см. табл. 1). Метасоматиты контролируются именно зонами бластокатаклаза вдоль разлома и представлены биотитили гастингсит-биотитовыми двуполевошпатовыми породами. Для метасоматитов Бирюсинской зоны характерны повышенные по отношению к гранитам концентрации Be, Sn, Th и РЗЭ (см. табл. 2), нами впервые здесь обнаружены концентрации до 60 г/т Ве, которые коррелируются с содержаниями фтора (рис. 3) и позволяют надеяться найти и более бериллоносные участки. Аномально высокие содержания тория распределены в метасоматитах неравномерно и приурочены часто к осевой зоне разлома. Природа аномалий не установлена. По сравнению с другими участками содержания РЗЭ в щелочных метасоматитах Бирюсы наиболее низки, но форма спектра такая же, с выраженным Еu минимумом (рис. 4).

Зона Приморского разлома характеризуется слабым развитием полевошпатовых метасоматитов. В отличие от Даванской и Бирюсинской зон метасоматиты непосредственно находятся в гранитах и являются постмагматическими. При этом сами граниты 1-й фазы приморского комплекса характеризуются повышенными концентрациями тех же редких элементов по сравнению со стандартными известковощелочными гранитами, что и метасоматиты (см. табл. 2). Распространенным акцессорием гранитов-рапакиви является флюорит. Наиболее интенсивно развита постмагматическая кислотная стадия метасоматоза. Гидротермально-метасоматические процессы в зоне разлома развивались в условиях понижающейся температуры и меняющейся кислотности-щелочности растворов. Это выражается в смене парагенезисов, при которой на биотит-микроклин-кварц-альбитовые метасоматиты накладываются процессы кислотного выщелачивания с образованием топаз-мусковит-кварцевых грейзенов и кварцевых метасоматитов кислотной стадии. Это мусковит-топазовые грейзены гольца Трехглавого [Базарова, 2011] и p. Улан-Хана с высокими содержаниями F (до 1.8 \%), Rb (до 1100 г/т). Sn (до 310), Nb (до 190), Се (до 550) [Собаченко и др., 1975] . В кварц-мусковитовых грейзенах по сравнению с гранитами повышены содержания Li, Sn, Nb, Th, U и W (до 218 г/т). Позднее вдоль зоны Приморского разлома, преимущественно в мелкозернистых гранитах второй фазы, вновь развиваются метасоматические процессы, сопровождающиеся редкометалльной минерализацией с накоплением как типично коровых элементов - $\mathrm{Li}$, $\mathrm{Rb}, \mathrm{Sn}, \mathrm{Be}, \mathrm{Mo}, \mathrm{W}, \mathrm{Bi}$, так и высокозарядных $\mathrm{Nb}, \mathrm{Ta}$, Р3Э, относимых обычно к мантийным. В зоне Приморского разлома в районе р. Улан-Хан щелочные метасоматиты, развитые в мелкозернистых биотитовых гранитах, несут молибденовую и колумбитовую минерализацию, а мусковит-топаз-альбит-кварцевые грейзены содержат висмутовую (до 1 \% Ві (висмутин,

Рис. 3. Распределение Ве и F в щелочных метасоматитах зон Даванского (1) и Бирюсинского (2) разломов.

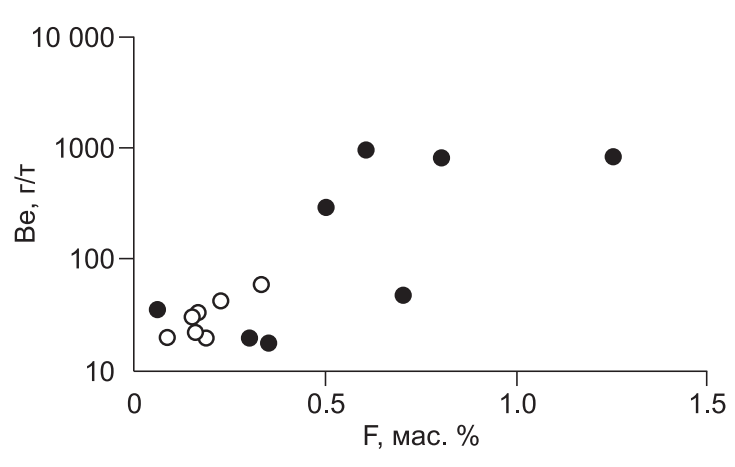



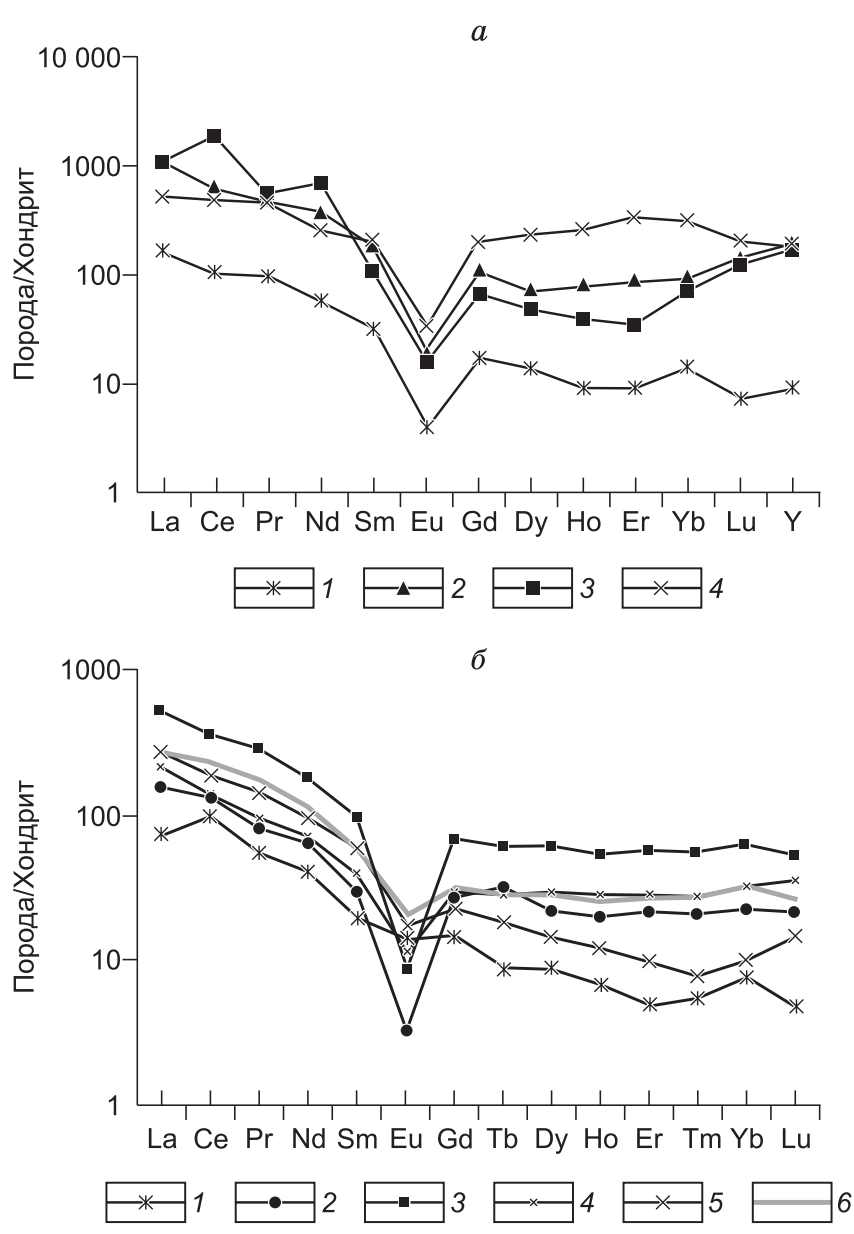

эти процессы происходили в два этапа. На раннем этапе развивался мощный бластокатаклаз, который сопровождался слабым изменением состава пород. По бластокатаклазитам, как и на Бирюсе, развивается мигматизация с образованием собственно щелочных метасоматитов, кварц-двуполевошпатовых с гастингситом или биотитом. Она отличается от более ранней гранитизации высокими концентрациями редких высокозарядных элементов $(\mathrm{Zr}, \mathrm{Hf}, \mathrm{Nb}$, РЗЭ, Тh, см. табл. 3, рис. 2).

В северной части зоны смятия, где нет выходов гранитов, видно, что щелочные метасоматиты развиваются и по гнейсам укучиктинской свиты, и по бластокатаклазитам. Выявить их можно только по высоким содержаниям редких и высокозарядных элементов ( $\mathrm{Zr}$ до 1900 г/т, $\sum$ РЗЭ до 0.2 мас. \%). Южнее, особенно в районе Даванского перевала, взаимоотношения метасоматитов и гранитов очень сложны, чему способствуют частые тектонические подвижки внутри зоны смятия. Гранитовидные метасоматиты, наряду с секущими контактами, имеют постепенные переходы в однородные граниты, по геохимическим особенностям от них малоотличимые. Граниты относят к ирельскому комплексу гастингситовых граносиенитов. Они встречаются не только внутри зоны смятия, но и в виде массивов и гранитогнейсовых куполов вне ее (Абчадский и Ирельский массивы). Позже формируются аляскитовые граниты, которые пересекают и метасоматиты, и граносиениты. Но аляскиты обогащены теми же элементами, что и щелочные метасоматиты (см. табл. 3), что свидетельствует о едином источнике растворов и расплавов.

Переход к кислотной и поздней щелочной стадиям метасоматоза осуществляется уже на постмагматическом этапе, что отражается в смене парагенезисов с одновременным ростом содержаний редких элементов. В плагиоклазах и темноцветных минералах увеличивается доля щелочных (Na-Li) миналов. Биотит-кварц-полевошпатовые парагенезисы ранних метасоматитов сменяются гастингсит-лепидомелан-микроклин-альбитовыми и далее - протолитионит-(фенгит)-альбит-кварцевыми и мусковит-альбит-кварцевыми в рудоносных грейзенах зоны Даванского разлома, что свидетельствует о заметном повышении кислотности растворов. Грейзены и слюдисто-кварц-полевошпатовые метасоматиты содержат бериллиевую (берилл, гальвин, даналит, фенакит, хризоберилл), танталониобиевую (фергусонит, самарскит, пирохлор, приорит), редкоземельную (алланит, гадолинит, монацит), оловянную (касситерит) и вольфрамовую (вольфрамит) минерализацию (по данным Собаченко В.Н.). Для грейзенов характерны 
самые высокие концентрации редких элементов, достигающие Sn (1380 г/т), W (111—181 г/т), Be (6070 г/т).

В Катугино-Аянской зоне, расположенной на периферии Катугинского прогиба, метаморфиты и мигматиты удоканской серии палеопротерозоя прорваны гранитоидами катугинского $(2100-2066$ млн лет, см. табл. 1) и рапакивиподобными гранитами кодарского комплекса (возраст 1800 млн лет). Каларский массив этих гранитов с северо-востока ограничивает более древнее Катугинское поле приразломных гранитовидных метасоматитов [Собаченко и др., 1988]. И граниты, и метасоматиты обогащены $\mathrm{Nb}$, $\mathrm{Zr}$, REE, Th, Be и Sn (см. табл. 3). Rb-Sr возраст метасоматитов составляет 2100 млн лет, $\left({ }^{87} \mathrm{Sr} /\right.$ $\left.{ }^{86} \mathrm{Sr}\right)_{0}=0.7720$. Щелочные метасоматиты близки по возрасту гранитам катугинского комплекса. В Катугино-Аянской зоне, как и в Даванской, развита гранитизация повышенной щелочности, что и является проявлением ранней щелочной стадии приразломного метасоматоза [Собаченко и др., 1993]. Приразломные щелочные метасоматиты представлены кварц-микроклин-альбитовыми породами. Фации метасоматитов выделены по темноцветным минералам, составы которых от внешних к внутренним зонам меняются по схеме: биотит-рибекит-арфведсонит-эгирин. Соответственно выделяются биотитовые, биотит-рибекитовые, рибекит-арфведсонитовые, арфедсонит-эгириновые и эгириновые фации приразломных гранитовидных метасоматитов.

По минеральному и химическому составам метасоматиты близки к щелочным гранитам и граносиенитам: $\mathrm{SiO}_{2}-69-74$ мас. \%, $\left(\mathrm{Na}_{2} \mathrm{O}+\mathrm{K}_{2} \mathrm{O}\right)-8.4-12.5$ мас. \%, $K_{\text {агп }}-1.0-1.3$ и выше. Главные петрохимические черты метасоматитов определялись высокотемпературными минеральными парагенезисами (микроклин-кварц-альбит плюс один или два указанных выше темноцветных минерала). Метасоматиты формировались в бластотектонитах гранитоидного, реже амфиболитового составов с участием глубинных флюидов при высокой химической активности натрия, а также фтора и содержат редкометалльную минерализацию [Архангельская и др., 1993; Собаченко и др., 1998].

Особенности изменения химического состава пород свидетельствут о том, что этот процесс являлся фторонатриевым метасоматозом и сопровождался накоплением в метасоматитах по сравнению с субстратом $\mathrm{Ta}, \mathrm{Nb}, \mathrm{Zr}$, лантаноидов и других редких элементов (см. табл. 3). Главными минералами-концентраторами РЗЭ в апоамфиболитовых метасоматитах являются пирохлор, гагаринит, флюоцерит. В метасоматитах последовательно возрастают содержания $\mathrm{Ta}, \mathrm{Nb}, \mathrm{Zr}$, Hf и других редких элементов, концентрации которых в арфведсонит-эгириновых метасоматитах достигают максимальных величин. Эти породы рассматриваются как комплексные Ta-Nb-Zr-P3Э-руды [Архангельская и др., 1993].

\section{ОБСУЖДЕНИЕ РЕЗУЛЬТАТОВ}

Таким образом, все перечисленные районы проявления приразломных щелочных метасоматитов приурочены к разломам, оперяющим зону краевого шва платформы, вдоль которых наиболее мощно прошла синсдвиговая тектоническая переработка пород. Причем последовательное изучение катаклазитов и метасоматитов показывает, что эти процессы происходили в два этапа: первый этаn - безрудный катаклаз, второй этап - развитие щелочных калиевых метасоматитов, обогащенных редкими элементами.

Изменения состава пород - собственно щелочной метасоматоз - происходили на втором этапе при активизации сдвиговых тектонических движений, снижении давления и увеличении проницаемости пород. При поступлении щелочных растворов формировались гранитовидные метасоматиты, обогащенные калием и редкими элементами. Причем редкометалльная нагрузка и возраст щелочных метасоматитов явно увеличивается с юго-запада на северо-восток (см. табл. 1). Так, метасоматиты Бирюсинского разлома обнаруживают как черты сходства, так и различия с гранитовидными метасоматитами Даванской зоны. Сходство условий образования метасоматитов в зонах Бирюсинского и Даванского региональных разломов проявляется в том, что их линейные тела развиты в грубоочковых бластотектонитах, состав которых меняется от сиенитодиоритов до граносиенитов (от 58-59 до 65-68 мас. \% $\mathrm{SiO}_{2}$ и суммы $\left(\mathrm{Na}_{2} \mathrm{O}+\mathrm{K}_{2} \mathrm{O}\right)$ от 5.5-6.0 до 8.5-10 мас. \% (калий преобладает над натрием). Однако щелочность бластотектонитов в Даванской зоне $\left(K_{\text {агп }}\right.$ до 0.88$)$ выше по сравнению с аналогичными образованиями в зоне Бирюсинского разлома $\left(K_{\text {агп }}\right.$ до $\left.0.55-0.62\right)$. Для калиевых щелочных метасоматитов обеих зон разломов характерна высокая кремнекислотность $\left(\mathrm{SiO}_{2}-71-77\right.$ мас. \%) при повышенной щелочности: $\left(\mathrm{Na}_{2} \mathrm{O}+\mathrm{K}_{2} \mathrm{O}\right)-7.48-9.70$ мас. $\%, K_{\text {агп }}-0.85-0.96$. В рудопроявлениях Даванской зоны смятия по сравнению с мусковит-кварц-альбитовыми метасоматитами зоны Бирюсинского разлома уровни концентраций Ве выше в $10-20$ раз, Rb в $2-10$ и Р3Э в $1.5-3$ раза.

Широкое участие фтора в метасоматических процессах, развитых в бластотектонитах Даванской зоны смятия и Приморской зоне, привело к более интенсивному проявлению в них бериллиевой и другой редкометалльной минерализации. O высоких исходных содержаниях F свидетельствуют акцессорный флюорит в гранитах и секущие флюоритовые прожилки в их краевых частях и зонах развития 

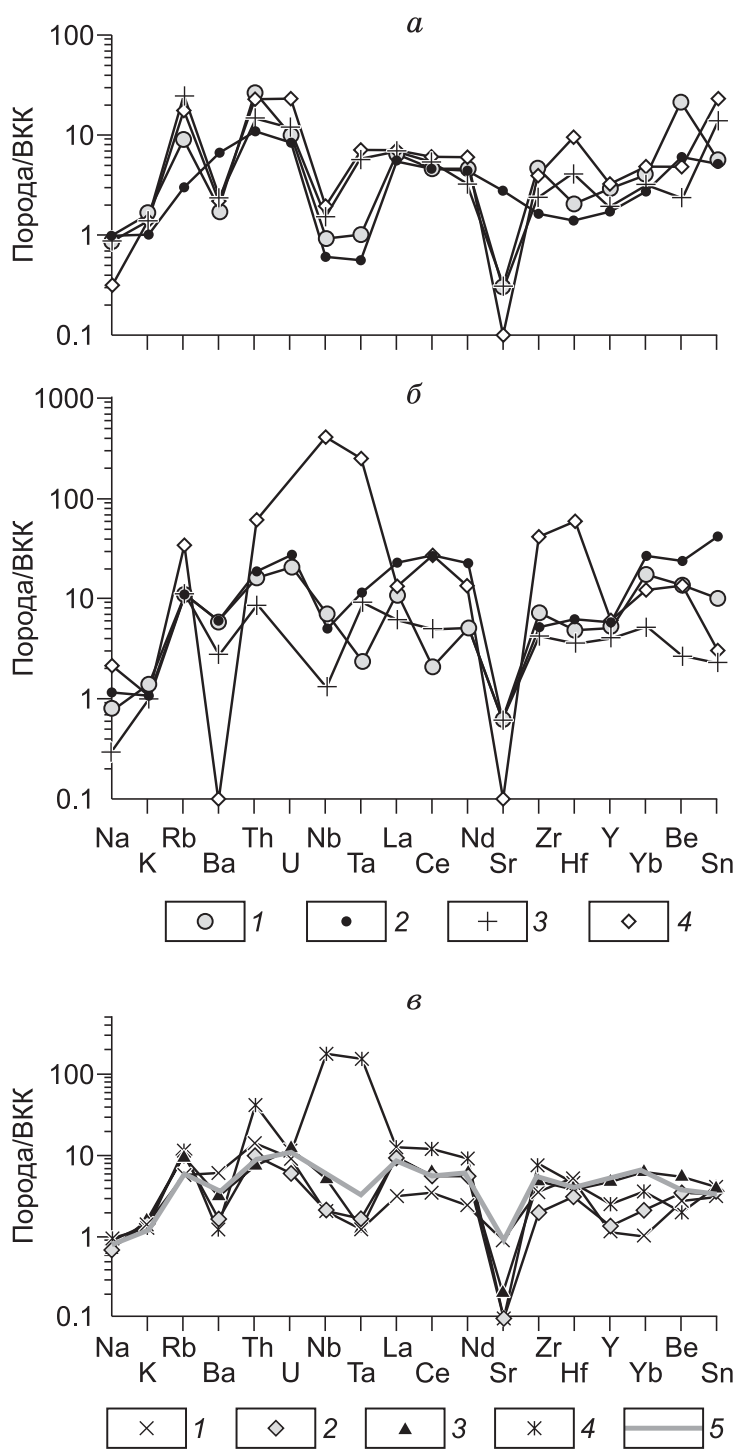

\section{Рис. 5. Редкоэлементные спайдер-диаграммы.}

$a$ - метасоматиты: 1,2 - щелочные и мусковит-кварц-альбитовые метасоматиты Бирюсинской зоны; 3, 4- микроклин-альбитовые метасоматиты и топаз-мусковитовые грейзены Приморского разлома; $6-1,2-$ щелочные метасоматиты и грейзены Даванской зоны; 3 , 4 - щелочные калиевые и натриевые метасоматиты Катугино-Аянской зоны; в - граниты комплексов: 1 - саянского, 2 - рапакивиподобные граниты приморского, 3 - ирельского, 4 - рапакиви кадарского и 5 - вулканиты СБВПП. Нормировано по ВКК [Тейлор, Мак-Леннан, 1988].

грейзенов. Видимо, комплексные соединения фтора с редкими элементами были главными их переносчиками. Даванская зона смятия непосредственно граничит с субщелочными кислыми метавулканитами СевероБайкальского вулканоплутонического пояса (СБВПП). С вулканитами этого пояса ассоциируют интрузии приморского комплекса гранитов-рапакиви и субщелочные гранитоиды ирельского комплекса. Все эти магматические образования несут сходную геохимическую характеристику со щелочными метасоматитами: высокие содержания $\mathrm{Zr}, \mathrm{P} 3 Э$, $\mathrm{Th}, \mathrm{Be}$ и $\mathrm{Sn}$, что особенно четко видно при сравнении распределения РЗЭ (рис. 4) и на спайдер-диаграммах (рис. 5).

В обнаженной части СБВПП видно, что вулканиты занимают рифтогенный прогиб вдоль южного края кратона, отделяясь от его шва Чуйским поднятием. Из современных вулканических поясов этот пояс наиболее близок к Провинции Бассейнов и Хребтов Северной Америки, которая является мощным проявлением надсубдукционного магматизма в краевой части материка. С юга на акитканские вулканиты надвинуты чуйские метаандезиты, которые по составу реконструируются как архейская активная окраина или островная дуга [Макрыгина, 1991]. Важной особенностью геохимии всех кислых магматитов и метасоматитов рассмотренных зон разломов являются очень низкие содержания стронция при высоких концентрациях рубидия. Такое соотношение обусловливает относительно повышенные количества ${ }^{87} \mathrm{Rb}$ и, соответственно, образующегося при распаде его ${ }^{87} \mathrm{Sr}$ по отношению к стабильному ${ }^{86} \mathrm{Sr}$. В результате первичные отношения $\left({ }^{87} \mathrm{Sr} /{ }^{86} \mathrm{Sr}\right)_{0}$ имеют очень высокие даже для коровых образований значения - от 0.72 до 0.82 , что косвенно свидетельствует о явном преобладании корового источника кислых пород.

Все эти образования - граниты, вулканиты и метасоматиты устойчиво характеризуются высокими содержаниями $\mathrm{K}, \mathrm{Rb}, \mathrm{Nb}, \mathrm{Zr}, \mathrm{Hf}, \mathrm{REE}, \mathrm{Th}, \mathrm{U}$, а также $\mathrm{Sn}, \mathrm{Be}, \mathrm{F}$, реже $\mathrm{W}$ и $\mathrm{Bi}$, вплоть до рудопроявлений. Это может свидетельствовать о едином источнике вещества и его эволюции по мере тектонического развития края континента: от механического бластокатаклаза при сдвигах вдоль оперяющих краевой шов разломов и проникновения щелочных растворов с рудной нагрузкой с формированием щелочных метасоматитов до плавления на более глубоких горизонтах с внедрением субщелочных рапакивиподобных гранитов со своей стадией развития постмагматического метасоматоза и до формирования наземных излияний кислых лав. При этом с юго-запада на северо-восток наблюдается увеличение концентраций редких и редкоземельных компонентов в метасоматитах (см. табл. 2, 3; рис. 4, 5), и темноцветные минералы становятся более щелочными. В этом же направлении резко возрастает роль фтора, соединения которого служат главными переносчиками редких элементов.

Кроме этого, в изученных зонах субщелочные крупнозернистые рапакивиподобные граниты ранней фазы сменяются мелкозернистыми известково-щелочными гранитами типа аляскитов, также обогащенными редкими элементами. Ранее предлагалась версия выплавки этой порции расплава из другого субстрата. Но более вероятной кажется версия быстрой потери расплавом летучих компонентов, связанная с активизацией тектонических движений в зоне и декомпрессией. Структуры протоклаза в рапаки- 
Рис. 6. Схематическое положение Сибирского кратона в период существования суперконтинентов Арктика, Родиния и в настоящее время [Глебовицкий и др., 2008].

Крестики - зона развития Акитканского вулканоплутонического пояса (если убрать чехол платформы). 1 - зона Бирюсинского разлома, 2 - зона Приморского разлома, 3 - Даванская зона смятия, 4 - Каларский разлом.

виподобных гранитах обусловлены быстрым подъемом частично закристаллизованного расплава. Резкий сброс давления мог привести к отделению и потере летучих. Это вызвало быструю кристаллизацию расплава 2-й фазы и формирование богатых фтором, натрием и другими редкими элементами растворов. Поэтому именно по мелкозернистым гранитам развиваются топаз-мусковит-альбитовые грейзены, богатые P3Э, $\mathrm{Nb}, \mathrm{Sn}, \mathrm{Be}, \mathrm{W}$ и другими редкими элементами.

При ощутимом разрыве во времени (около 200 - 150 млн лет) образований гранитоидов, вулканитов и метасоматитов наблюдается полное сходство их геохимических особенностей. Это свидетельствует о парагенетической связи магматического и метасоматического процессов.

Во времени процесс начинался с северо-востока, где граниты катугинского комплекса и щелочные метасоматиты имеют возраст 2100-2014 млн лет, в Даванской зоне это уже 1860 и 1740 млн лет и в Бирюсинской - 1858 и 1652 млн лет. При частых тектонических подвижках это может свидетельствовать о пульсационном поступлении калиевых щелочных растворов с затуханием тектонической и рудогенерирующей активности вдоль шва кратона с востока на запад (в современных координатах).

Остро стоит вопрос о соотношении во времени метасоматитов и гранитов. Во всех трех районах метасоматиты на 85, 120 и 200 млн лет моложе развитых на этих участках гранитоидов. В Бирюсинской и на севере Даванской зоны метасоматиты развиваются непосредственно по бластокатаклазитам при отсутствии поблизости гранитоидов. В то же время геохимические характеристики их сходны. Большой перерыв во времени свидетельствует о парагенетической связи метасоматитов и гранитов, источники которых - расплавы и растворы - используют одинаковые системы разломов. Еще более запутывает эти соотношения проявления собственного, близкого во времени проявления постмагматического метасоматоза, развитого по гранитам и непосредственно около них (приморский комплекс). Несомненно, для решения этого вопроса необходимы детальные изотопные исследования, что планируется провести в будущем.

Время появления калиевых кислых магматитов и метасоматитов приходится на период создания и перестройки серии суперконтинентов от Арктики (2.2 млрд лет), Нэны 2-1.8 млрд лет до Родинии 10.7 млрд лет [Rogers, 1996] (рис. 6). Сибирский кратон и его отдельные блоки испытывали при этом сдвиговые и ротационные движения (см. рис. 6). В вулканитах СБВПП преобладают значения возрастов $1.9-1.87$ млрд лет, когда начинается собственно акитканский кислый вулканизм, который по составу имеет внутриплитные характеристики [Булдыгеров, Собаченко, 2005]. Мощные тектонические перестройки испытывали все кратоны Земли: это был период полного разделения оболочек планеты и создания калиевого гранитного слоя в верхней коре. По-видимому, в это время особенно активно поднимались к поверхности потоки литофильных элементов, что и привело к формированию месторождений в метасоматитах. Приразломные метасоматиты развивались на пересечениях разломов на всех континентах (Канада, Украинский щит и др., [Кушев, 1972; Кущ, 2010]. Именно на этот период приходится большая доля редкометалльных месторождений мира. Однако Сибирский кратон существенно отличается от них: на нем преобладают калиевые магматиты и метасоматиты, а на Украине и в Канаде - альбитовые ураноносные метасоматиты. 


\section{ВЫВОДЫ}

Проведено сопоставление тектонического положения, этапов развития и геохимических особенностей щелочных приразломных метасоматитов и гранитоидов зоны краевого шва юга Сибирской платформы.

Выявлена приуроченность щелочных метасоматитов к разломам, оперяющим краевой шов платформы, вдоль которых на постметаморфическом этапе прошел мощный бластокатаклаз — это зоны Бирюсинского разлома, Даванской зоны смятия и Каларского разлома. Развитие зон бластокатаклаза является первым безрудным этапом, предваряющим метасоматоз. Мощность зон варьирует от $1-2$ км в Бирюсинской до 25 км в Даванской зоне смятия.

Продолжающиеся тектонические подвижки увеличивают глубину и проницаемость разломов для кремнекалиевых растворов. На этом втором этапе по бластокатаклазитам формируются гранитовидные щелочные метасоматиты (ранняя щелочная стадия). Их индикаторами является повышение концентраций $\mathrm{K}, \mathrm{Zr}, \mathrm{Hf}, \mathrm{Nb}$, РЗЭ. Наиболее мощно эта стадия развита в Даванской зоне смятия.

Повышение кислотности растворов со снижением температуры приводит к проявлению кислотной стадии метасоматоза. Это кварц-мусковитовые метасоматиты в Бирюсинской зоне, грейзены с Sn, $\mathrm{Be}, \mathrm{Th}, \mathrm{W}, \mathrm{U}, \mathrm{P} 3 Э$ минерализацией вплоть до рудопроявлений и месторождений в Даванской и КатугиноАянской зонах. В последней широко развита и поздняя щелочная стадия натриевого метасоматоза с богатой рудной минерализацией. Масштаб метасоматических изменений, их возраст и рудоносность зон снижается вдоль краевого шва с северо-востока на юго-запад. Но вследствие частых тектонических подвижек четкая метасоматическая зональность на отдельных участках наблюдается редко.

Вдоль краевого шва расположены выходы субщелочных калиевых гранитоидов приморского и ирельского комплексов. По геохимическим особенностям они близки щелочным метасоматитам, но во времени чаще всего разделены. Только в гранитах приморского комплекса прослеживаются все стадии постмагматического метасоматоза, аналогичные по геохимическим особенностям приразломным метасоматитам изученных зон. Интересно, что образующийся в этом же интервале времени в рифтовой системе вдоль краевого шва мощный вулканоплутонический пояс (СБВПП) имеет те же геохимические характеристики, что и граниты, и метасоматиты.

Такое совпадение тектонического положения, интервала времени образования (2.1-1.6 млрд лет) и спектра редких элементов свидетельствует о парагенетической связи гранитов, метасоматитов и вулканитов, родившихся в длительном процессе сдвигового и ротационного движения кратона и его блоков [Диденко и др., 2005], которое приводило к резким сменам давления вдоль оперяющих шов разломов с механической переработкой пород и поступлением коровых и глубинных растворов, а также расплавов. Преобладание корового вещества подтверждается кислым составом, обилием редких элементов, особенно калия, фтора, олова, бериллия и тория, а главное - аномально высокими первичными отношениями $\left({ }^{87} \mathrm{Sr} /{ }^{86} \mathrm{Sr}\right)_{0}$ до $0.71-0.82$.

Работа выполнена при поддержке гранта РФФИ 11-05-00515a, интеграционного проекта ОНЗ-9.3 и научной школы НШ-6153.2012.5.

\section{ЛИТЕРАТУРА}

Апельцин Ф.Р. Гранитный магматизм и редкометалльное оруденение // Рудообразование и его связь с магматизмом. М., Наука, 1972, с. 28-71.

Архангельская В.В., Казанский В.И., Прохоров К.В., Собаченко В.Н. Геологическое строение, зональность и условия образования Катугинского Ta-Nb-Zr месторождения (Чаро-Удоканский район, Восточная Сибирь) // Геология рудных месторождений, 1993, т. 35, № 2, с. 115-131.

Базарова Е.П. Петрология и геохимия раннепротерозойских гранитов приморского комплекса: Автореф. ... к.г.-м.н. Иркутск, 2011, 21 с.

Белевцев Я.Н. Метаморфогенное рудообразование. М., Недра, 1979, 275 с.

Бухаров А.А., Халилов В.А., Страхова Т.М., Черников В.В. Геология Байкало-Патомского нагорья по новым данным уран-свинцового датирования акцессорного циркона // Геология и геофизика, 1992 (12), с. $29-39$.

Булдыгеров В.В., Собаченко В.Н. Проблемы геологии Северо-Байкальского вулканоплутонического пояса. Иркутск, РИЦ ИГУ, 2005, 184 с.

Генко Г.А., Львов В.К. Анализ данных о глубинном строении территории БАМ // Геология, геофизика и полезные ископаемые региона Байкало-Амурской магистрали (Тр. ВСЕГЕИ, вып. 1). 1977, c. $28-35$.

Гинзбург А.И., Апельцин Ф.Р. Редкометалльные месторождения, их связь с магматизмом и тектоническими структурами земной коры // Геология рудных месторождений, 1970, т. 12, № 2, с. 25 - 37. 
Гинзбург А.И., Архангельская В.В., Шацкая В.Т. Полевошпатовые метасоматиты - новый генетический тип месторождений полезных ископаемых // Разведка и охрана недр, 1973, № 1, с. 71-79.

Глебовицкий В.А., Хильтова В.Я., Казаков И.К. Тектоническое строение Сибирского кратона: интерпретация геолого-геофизических и изотопно-геохимических данных // Геотектоника, 2008, № 1, c. $12-26$.

Гольцман Ю.В., Бибикова Е.В., Баирова Э.Д., Аракелянц Е.М., Буякайте М.И., Кориковский С.П., Федоровский В.С. Геохронология гранитов приморского комплекса Юго-Западного Прибайкалья по данным U-Pb, Rb-Sr, K-Ar методов // Изв. СССР. Сер. геол. 1982, № 1, с. 5-15.

Гореванов Д.Е., Халилов В.А. О возрасте тектонитов зоны Приморского разлома (Западное Прибайкалье) // РФФИ в Сибирском регионе (земная кора и мантия). Иркутск, 1995, с. 31-33.

Диденко А.Н., Водовозов В.Ю., Козаков И.К., Бибикова Е.В. Палеомагнитное и геохронологическое изучение постколлизионных раннепротерозойских гранитоидов юга Сибирской платформы: методические и геодинамические аспекты // Физика Земли, 2005, № 2, с. 66-83.

Донская Т.В., Бибикова Е.В., Мазукабзов А.М., Козаков И.К., Гладкочуб Д.П., Кирнозова Т.И., Плоткина Ю.В., Резницкий Л.З. Приморский комплекс гранитоидов Западного Прибайкалья: геохронология, геодинамическая типизация // Геология и геофизика, 2003 (10), с. 1006-1016.

Казанский В.И., Омельяненко Б.И., Прохоров К.В. Рудоносные щелочные метасоматиты в крупных разломах кристаллического фундамента // Эндогенное оруденение древних щитов. М., Наука, 1978, c. $102-144$.

Кирнозова Т.И., Бибикова Е.В., Козаков И.К., Ковач В.П., Диденко А.Н., Резницкий Л.З. Раннепротерозойские коллизионные гранитоиды Присаянского выступа фундамента Сибирской платформы: геохронологические и $\mathrm{Sm}-\mathrm{Nd}$ изотопные данные // Изотопная геохронология и решение проблем геодинамики и рудогенеза. Материалы II Российской конф. по изотопной геохронологии. СПб., Центр информационной культуры, 2000, с. 193-195.

Колотилина Т.Б., Мехоношин А.С. Гранатовые ультрамафиты и ассоциирующие метабазиты Бирюсинского блока (юг Сибири) // Геология и геофизика, 2001, т. 42 (8), с. 1221-1236.

Кушев В.Г. Щелочные метасоматиты докембрия. Л., Недра, 1972, 189 с.

Кущ Л.В. Геохимия и условия формирования редкометалльных метасоматитов в зонах Бирюсинского и Даванского разломов (юг Сибирской платформы): Автореф. ... к.г.-м.н. Иркутск, 2010, 25 с.

Ларин А.М., Котов А.Б., Сальникова Е.Б., Ковач В.П., Макарьев Л.Б., Тимашков А.Н., Бережная Н.Г., Яковлева С.3. Новые данные о возрасте гранитов кодарского и тукурингрского комплексов (Восточная Сибирь): геодинамические следствия // Петрология, 2000, т. 8, № 3, с. 267-279.

Ларин А.М., Котов А.Б., Сальникова Е.Б., Коваленко В.И., Ковач В.П., Яковлева С.3., Бережная Н.Д., Иванов В.Э. О возрасте Катугинского Та-Nb-месторождения (Алдано-Становой щит): к проблеме выделения новой глобальной редкометалльной металлогенической эпохи // ДАН, 2002, т. 383, № 6, c. $807-811$.

Ларин А.М., Сальникова Е.Б., Котов А.Б., Коваленко В.И., Рыцк Е.Ю., Яковлева С.З., Бережная Н.Д., Ковач В.П., Булдыгеров В.В., Срывцев Н.А. Северо-Байкальский вулканоплутонический пояс: возраст, длительность формирования и тектоническое положение // ДАН, 2003, т. 392, № 4, c. $506-511$.

Левицкий В.И., Мельников А.И., Резницкий Л.З., Бибикова Е.В., Кирнозова Т.И., Козаков И.К., Макаров В.А., Плоткина Ю.В. Посткинематические раннепротерозойские гранитоиды югозападной части Сибирской платформы // Геология и геофизика, 2002, т. 43 (8), с. 717-731.

Макрыгина В.А. Геохимия метаморфизма и ультраметаморфизма умеренных и низких давлений. Новосибирск, Наука, 1981, 199 с.

Макрыгина В.А. Геохимия катаклазитов иловирской свиты и их природа // Геохимия, 1991, № 6, c. $878-888$.

Макрыгина В.А., Бакшеев С.А. Редкоземельные элементы в щелочных метасоматитах Кутимской глыбы // Геохимия редкоземельных элементов в эндогенных процессах. Новосибирск, Наука, 1982, c. $153-164$.

Макрыгина В.А., Петрова З.И., Сандимирова Г.П., Пахольченко Ю.А. Новые данные о возрасте толщ, обрамляющих Чуйское и Прибайкальское поднятия (Северное и Западное Прибайкалье) // Геология и геофизика, 2005, т. 46 (7), с. 714-722.

Макрыгина В.А., Беличенко В.Г., Резницкий Л.3. Типы палеоостровных дуг и задуговых бассейнов северо-восточной части Палеоазиатского океана (по геохимическим данным) // Геология и геофизика, 2007, т. 48 (1), с. 141-155.

Миркина С.Л. О возрасте Катугинского месторождения // Эндогенные процессы и металлогения в зоне БАМ. Новосибирск, Наука, 1983, с. 147-149. 
Мехоношин А.С., Колотилина Т.Б., Орсоев Д.А., Владимиров А.Г., Травин А.В., Хромых С.В., Юдин Д.С. Индикаторная роль базит-ультрабазитовых комплексов в интерпретации геодинамической природы тектонических блоков южного обрамления Сибирского кратона // Геодинамическая эволюция литосферы Центрально-Азиатского подвижного пояса (от океана к континенту). Иркутск, 2005, т. 2, c. $49-52$.

Неймарк Л.А., Миркина С.Л., Ризванова Н.Г., Кузина Н.А., Рудакова Ж.Н. Уран-свинцовый возраст гранитоидов ирельского комплекса и связанных с ним метасоматитов // Проблемы изотопного датирования процессов метаморфизма и метасоматоза. М., 1985, с. 114-115.

Неймарк Л.А., Миркина С.Л., Рублев А.Г., Ризванова Н.Г., Кузина Н.А., Рудакова Ж.Н. Возраст гранитоидов ирельского комплекса Прибайкалья по радиологическим данным // Изв. АН СССР, сер. геол. 1987, № 5, с. 18-25.

Неймарк Л.А., Ларин А.М., Яковлева С.З., Срывцев Н.А., Булдыгеров В.В. Новые данные о возрасте пород акитканской серии Байкало-Патомской складчатой области по результатам U-Pb датирования цирконов // Докл. АН СССР, 1991, т. 320, № 1, с. 182-186.

Петрова 3.И., Макрыгина В.А., Антипин В.С. Петролого-геохимическая корреляция гранитов рапакиви и кислых вулканитов в южном обрамлении Сибирской платформы // Петрология, 1997, т. 5, № 3, c. $291-311$.

Прохоров К.В., Собаченко В.Н. Структурно-петрологические и геохимические условия образования рудоносных высокотемпературных натриевых метасоматитов // Внутреннее строение рудоносных докембрийских разломов. М., Наука, 1985, с. 94-121.

Рудник В.А., Беляев Г.М., Терентьев В.М. Закономерности формирования кварц-полевошпатовых метасоматитов зон региональных разломов // Проблемы метасоматоза. М., Недра, 1970, с. 261274.

Савельева В.Б., Базарова Е.П. Геохимические особенности, условия кристаллизации и потенциальная рудоносность раннепротерозойского приморского комплекса гранитов рапакиви (Западное Прибайкалье) // Геология и геофизика, 2012, т. 53 (2), с. 193-218.

Сезько А.И. Основные этапы формирования континентальной коры Присаянья // Эволюция земной коры в докембрии и палеозое // Саяно-Байкальская горная область. Новосибирск, Наука, 1988, c. $61-67$.

Собаченко В.Н. О гранитоидах, повторной гранитизации и метасоматических процессах в зонах глубинных разломов Западного Прибайкалья // Геохимия и петрология метасоматоза. Новосибирск, Наука, 1975, с. 44-62.

Собаченко В.Н. Геохимические условия проявления редкометалльных метасоматитов в докембрийских троговых структурах Удоканского района (Северо-Восточное Забайкалье) // Докембрийские троговые структуры Байкало-Амурского региона и их металлогения. Новосибирск, Наука, 1985, с. 133139.

Собаченко В.Н. К проблеме генезиса крупных редкометалльных месторождений, связанных с приразломными метасоматитами в породах докембрия юга Восточной Сибири // Крупные и уникальные месторождения редких и благородных металлов. СПб., 1998, с. 83-93.

Собаченко В.Н., Кущ Л.В. Гранитоиды и метасоматиты протерозоя в зоне Бирюсинского разлома Восточного Саяна // Вестник Гео ИГУ, вып. 4, Иркутск, 2005, с. 25- 45.

Собаченко В.Н., Плюснин Г.С., Сандимирова Г.П., Пахольченко Ю.А. Первые результаты Rb-Sr датирования процессов гранитизации в Даванской зоне смятия (Северо-Западное Прибайкалье) // Докл. AH CCCP, 1988, т. 301, № 1, c. 202-206.

Собаченко В.Н., Архангельская В.В., Казанский В.И., Прохоров К.В. Геологическое строение, зональность и условия образования Катугинского Ta-Nb-Zr-месторождения (Чаро-Удоканский район, Восточная Сибирь) // Геология рудных месторождений, 1993, т. 35, № 2, с. 115-131.

Собаченко В.Н., Сандимирова Г.П., Исакова Л.В., Пахольченко Ю.В. Рубидий-стронциевое датирование метасоматитов зоны Бирюсинского разлома Восточного Саяна // Докл. РАН, 1998, т. 362, № 2, c. 252-255.

Срывцев Н.А., Сандимирова Г.П., Кутявин Э.П. О возрасте двупироксеновых гранитоидов татарниковского комплекса Северо-Западного Прибайкалья // Геохронология Восточной Сибири и Дальнего Востока. М., Наука, 1980, с. 101-110.

Таусон Л.В., Собаченко В.Н., Плюснин Г.С., Сандимирова Г.Н., Николаев В.Н., Пахольченко Ю.А., Рейхвиашвили О.И. Рубидий-стронциевый возраст рапакивиподобных гранитов и метасоматитов Катугино-Аянской зоны (Северо-Восточное Забайкалье) // Докл. АН СССР, 1983, т. 273, № 5, c. $1233-1236$.

Тейлор С.Р., Мак-Леннан С.М. Континентальная кора, ее состав и эволюция. М., Мир, 1988, 379 c. 
Туркина О.М., Бибикова Е.В., Ножкин А.Д. Этапы и геодинамические обстановки раннепротерозойского гранитообразования на юго-западной окраине Сибирского кратона // Докл. РАН, 2003, т. 388, № 6, с. 779-783.

Afonin V.P., Finkelstein A.L., Borkhodoev V.J., Gunicheva T.N. X-ray fluorescence analysis of rocks by fundamental parameter method // X-ray Spectrometry, 1992, v. 21, p. 69-75.

Geostandards Newletters. 1994, V/ XVIII, Spec. Issue, July, 1994.

Rogers J.J.W. A history of continents in the past three billion years // J. Geology, 1996, v. 104, № 1, p. $91-108$.

Sun S-S., McDonough W.F. Chemical and isotopic systematics of oceanic basalts: implications for mantle composition and processes // Magmatism in the oceans basins. Geol. Soc. Special Publ., 1989, № 42, p. $313-345$. 